\title{
SPATIAL VARIABILITY OF MACROZOOBENTHIC COMMUNITY AND TROPHIC STRUCTURE OF A SUBTROPICAL LAGOON ON SOUTHEASTERN BRAZIL'S ATLANTIC COAST
}

\author{
Elena Ricevuto $^{1, *}$ Salvatrice Vizzini ${ }^{2}$, Claudio Lardicci ${ }^{3}$ and Abilio Soares Gomes ${ }^{4}$ \\ ${ }^{1}$ Stazione Zoologica "Anton Dohrn" di Napoli Villa Dohrn \\ (Punta S. Pietro 80077 Ischia, Napoli, Italy) \\ ${ }^{2}$ Dipartimento di Scienze della Terra e del Mare, Università degli Studi di Palermo \\ (Via Archirafi 18, 90123 Palermo, Italy) \\ ${ }^{3}$ Dipartimento di Biologia, Università di Pisa \\ (Via Derna 1, 56126 Pisa, Italy) \\ ${ }^{4}$ Universidade Federal Fluminense Rio de Janeiro \\ Departemento de Biologia Marinha \\ (Outeiro São João Batista, s/nº, 24001-970 Niterói, Rio de Janeiro, Brasil) \\ *Corresponding author: elenaricevuto@gmail.com
}

\begin{abstract}
A B S T R A C T
The objective of this study was to investigate the macrobenthic community of two compartments of the Maricá-Guarapina lagoon system, along the coast of Rio de Janeiro, Brazil, in relation to its abiotic sediment factors. An additional discrimination between sites was made, wherever the macrophyte Typha domingensis was found. This vegetation supposedly represents a potentially important food source for consumers. Furthermore, the trophic pathways were analyzed functionally by means of stable isotope analysis to assess the role of organic matter sources for consumers in the study area. In conclusion, the results showed differences between abiotic features in the compartments of the lagoon system, which, although they have affected the different species' distribution, have led to a homogeneous low-diversity system. Macrozoobenthic species tend to change with increasing distance from the sea, with a slightly different distribution in the two compartments. The macrophyte $T$. domingensis did not exercise any great influence on the biotic distribution and was not the main food source for consumers in the lagoon system, where, instead, sedimentary organic matter and macrophyte detritus also seem to play an important role in the trophic web.
\end{abstract}

\section{RESUMO}

O objetivo deste trabalho foi estudar a comunidade macrobentônica em dois compartimentos do sistema lagunar Maricá-Guarapina, situado na costa sudeste do Brazil, relacionando com fatores abióticos do sedimento. Adicionalmente, foi feita uma discriminação entre locais com e sem a presença da macrofita Thypha dominguensis, que supostamente representa uma importante fonte alimentar para os consumidores dos sistemas lagunares. A contribuição das macrofitas e outras fontes primárias de alimento para a rede trófica local foi investigada através do método das análises isotópicas. In conclusão, os resultados obtidos mostraram que os fatores abióticos diferiram pouco entre os compartimentos estudados, embora pareçam influenciar a distribuição do macrobentos local, que se caracteriza por uma baixa diversidade específica. As espécies do macrobentos tendem a mudar com o distanciamento do canal de conexão com o mar, existindo pouca diferença na estrutura da comunidade nos dois compartimentos. Igualmente, a presença da macrófita não influenciou a distribuição do macrobentos e os resultados da análise isotópica indicaram que a referida macrófita não representa fonte alimentar importante para os consumidores locais. Por sua vez, a matéria orgânica sedimentar e detritos de macrófitas parecem exercer um papel importante na rede trófica desse sistema lagunar.

Descriptors: Brazil, Macrozoobenthos, Stable Isotopes, Subtropical Coastal Lagoon. Descritores: Brasil, Macroozoobenthos, Isótopos Estáveis, Sistema Lagunar Costeiro Subtropical 


\section{INTRODUCTION}

According to Moreno et al. (2010), coastal lagoons occupy about $10 \%$ of the world's coastal areas and represent feeding, nursery, reproduction and protection spots for invertebrates, fishes and birds, as well as rich fishery grounds. Due to their location between the continent and the sea and their shallow depths, coastal lagoons are highly productive ecosystems (yielding an average of $300 \mathrm{~g} \mathrm{C} \mathrm{m}^{-2} \mathrm{y}^{-1}$, MOUILLOT et al., 2005; KNOPPERS, 1994), as the result of several factors, such as the high number of primary producers, the great input of nutrients and their efficient recycling (VIZZINI; MAZZOLA, 2008).

In accordance with Kjerfve's classification (1994), we can distinguish coastal lagoons as either choked, restricted or leaky systems, depending on the nature and number of the channels connecting them to the sea and the volume of water exchanged with the coastal ocean. Choked lagoons present reduced tidal oscillations and are connected by one single entrance to the sea, allowing an exchange of water, sediments, dissolved materials and organisms between the lagoon and the open sea. This channel can act as a natural dynamic filter largely reducing tidal fluctuations. Moreover these systems are characterized by a rapidly decreasing tide gradient, so that, in consequence, the inner compartment is not greatly influenced by marine conditions. Restricted lagoons, instead, lying parallel to the shore, usually present more than one inlet or channel to the open sea, resulting in water bodies with regular tidal circulation. Moreover their salinities can vary from those of brackish to oceanic waters. Finally, leaky lagoons are those with many channels connecting them to the ocean and are characterized by a close relationship to it as regards wave action, tidal currents and salinity, and consequently present characteristics very similar to those of the coastal ocean.

At present, nearly $40-50 \%$ of the world's population lives within $100 \mathrm{~km}$ of the coastline, including some of its largest cities (CROSSLAND et al., 2005). Many lagoons have been exploited and have been filled with nutrient discharges from agricultural and other human activities (ROSSI et al., 2006), leading to the gradual decline of their environmental quality. This constitutes a grave problem since transitional waters host important economic activities such as aquaculture, fisheries and tourism. Recently, the progressive intensification of human pressure on coastal environments has highlighted the fundamental importance of intensifying the study of these ecosystems and their management. Human pressure from urbanization is increasingly affecting the natural habitats of lagoons all over the world (KNOPPERS, 1991).
The implementation of baseline studies and management strategies for these ecosystems has been promoted in recent decades and important studies have been undertaken on the effect of nutrient concentrations, organic loads on the benthic fauna and the relationship between organic matter enrichment, chemical characteristics of the sediments, macrozoobenthic assemblages and the trophic structure of the lagoon (DRAKE; ARIAS, 1997; LARDICCI et al., 2001a; GAMBI et al., 2003; DE FALCO et al., 2004; COMO et al., 2007; PONTI et al., 2007) even if, as at present, little information is available on this last aspect (MAGNI et al. 2008).

In view of the above, there is an urgent need to characterize lagoon systems, especially when they are possibly being affected by anthropogenic influences, and to accumulate sufficient information to create a fuller understanding of the ecosystem studied.

In recent years, stable isotope analysis has widely come to be accepted as a reliable method for the examination of trophic structure over time and space, as also in complex ecosystems such as coastal lagoons (VIZZINI; MAZZOLA, 2008). This technique allows quantitative and non-intrusive investigation of ecological and environmental questions, and thus offers considerable advantages over other techniques. As carbon and nitrogen from producers pass from one trophic level to the next, their $\delta^{13} \mathrm{C}$ and $\delta^{15} \mathrm{~N}$ values tend to increase due to the differential use of heavy and light isotopes during metabolism (FRY; SHERR 1984, PETERSON; FRY 1987) and as long as nutrient sources for consumers are isotopically distinct, then nutrient pathways can be distinguished (JARDINE et al., 2003). As a consequence, stable isotope techniques can also be used to trace consumers' carbon and nitrogen sources and those of their food sources in order to assess the trophic interactions in the food web. Furthermore, with the progressive intensification of human pressure on coastal environments, the isotopic approach has been successfully used for detecting anthropogenic organic matter in marinecoastal ecosystems and investigating its dispersal and fate (NIXON et al., 2007, VIZZINI, 2005a, VIZZINI; MAZZOLA, 2006).

Coastal lagoons are abundant on the Brazilian coast, especially in Rio de Janeiro and Rio Grande do Sul States (ESTEVES, 1998). The coastal lagoons of northern Rio de Janeiro State have undergone various anthropogenic impacts since the first half of the XXth century (SOFFIATI, 1998). These ecosystems can mainly be considered choked systems and subject to increasing anthropogenic pressure. In spite of their importance as priority habitats all over the world, only scant information is yet available on their biological organization and above all on such trophic features as organic matter production by basic sources and its transfer into food 
webs is little understood. While in the literature (HENRIQUES-DE-OLIVEIRA, 2007) it is known that in tropical coastal lagoons the primary productivity of macrophytes is relatively more important than the phytoplankton productivity, no data are available about its fate in food webs. Thus, this research deals with the biotic and abiotic characterization and isotopic investigation of organic matter and its consumers in the Maricá-Guarapina lagoon system, an important and large brackish basin of the Fluminense region located on the southern Brazilian coastline, not yet studied from an ecological point of view.

The aim of this study was to assess the macrobenthic community of two compartments of the lagoon system and its relationship with abiotic features. More specifically, a comparison between the two zones of the lagoon has been made, discriminating sites presenting the macrophyte Typha domingensis from sites that do not present it or any other kind of vegetation, in order to detect a possible influence of the macrophyte on the structure of the abiotic and biotic features of each compartment. Additionally, we sought to make a functional analysis of different trophic levels through the use of stable isotope analysis to investigate the role of organic matter sources as regards consumers in the lagoon.

\section{Material ANd Methods}

Study Area

The Maricá-Guarapina lagoonal system is located along the subtropical coastline of the Brazilian Rio de Janeiro state, about $50 \mathrm{~km}$ from the capital city Rio de Janeiro, in the municipality of Maricá. This area is a tourist attraction, being of great environmental, social and economic importance both at local and regional level (MADUREIRA CRUZ et al., 1996). The system consists of four coastal lagoons connected by channels and is one of the biggest lagoon systems in the state. Potential anthropogenic impacts for the system are related to urbanization and farming. The mechanical extraction of clay and sand have recently become the most important local industrial activities, and are possibly responsible for the eutrofication of and increased nutrient concentration in the lagoon. Moreover the area is characterized by increasing anthropogenic pressure, with lack of organization and urban planning, especially of basic sanitary infrastructure (GUERRA et al., 2011). The environment appears to be deteriorated, not only that of the Maricá-Guarapina lagoon system, but also that of the other lagoon systems of the area, known as the "região norte fluminense".

The lagoonal system is composed of four distinct interconnected compartments: Maricá, Padre, Barra and Guarapina, covering about $34.87 \mathrm{~km}^{2}$. Maricá and Barra are the biggest compartments of, respectively, $18.21 \mathrm{~km}^{2}$ and $8.12 \mathrm{~km}^{2}$ (Fig. 1). The system's catchment basin lies between $22^{\circ} 53$ ' and $22^{\circ}$ $58^{\prime} \mathrm{S}$, and $42^{\circ} 40^{\prime}$ and $43^{\circ} \mathrm{W}$ and includes three subbasins, those of the Vigario, Ubatiba and Caranguejo rivers. All these rivers have a low rate of flow. The Caranguejo flows into the Guarapina compartment and the Vigario and Ubatiba into Maricá (BARROSOVANACÔR et al., 1994).

In this study, the two outer lagoons of Maricá and Guarapina are regarded as distinct. In fact, the former is considered an "inner" compartment and the latter more external, for it has a narrow channel (canal da Ponta Preta) opening directly into the sea. This configuration of the system, shallow and little influenced by tides, allows us to classify it as a choked lagoon system, according to Kjerfve's definition (1986). In addition, a second channel (canal da Costa) has been opened, connecting the Maricá compartment to the sea, but it gave rise to controversy, for it is very long and apparently does not contribute positively - in the way the one that links the Guarapina compartment to the sea does - to the water exchange of the compartment.

According to Madureira Cruz et al. (1996), Maricá is the compartment that presents the most worrisome situation in relation to urbanization as it is used as a landfill and receives untreated sewage. Despite which, it is largely used for artesanal fishing. Guarapina has also lately been affected by strong human pressure from urbanization, although in the literature it is considered a rural basin (KNOPPERS et al., 1991).

As most southern Brazilian coastal lagoons, the Maricá-Guarapina lagoonal system has a microtidal regime, with a tidal range between 0.1 and 0.4 meters.

The region is characterized by a subtropical humid climate with an annual precipitation of 1100 $\mathrm{mm}$, reaching the maximum peak of $277 \mathrm{~mm}$ in the austral summer (113 $\mathrm{mm}$ in December) and a minimum of $171 \mathrm{~mm}$ during the austral winter $(42 \mathrm{~mm}$ in August). According to Knopper (1991), for most of the fluminense lagoons, the direct rainfall and evaporation from the lagoon surface are approximately in balance. 


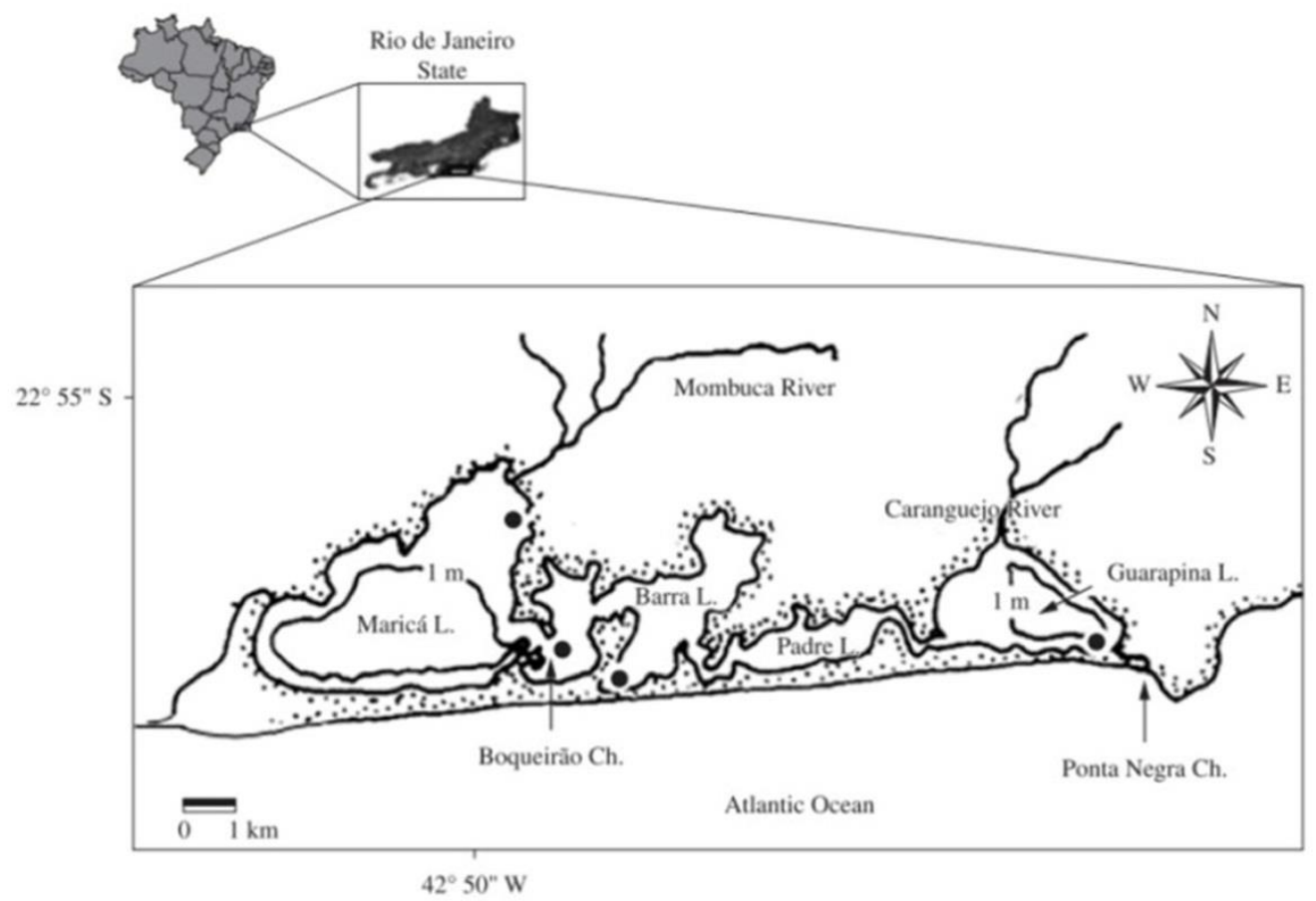

Fig. 1. Study area.

The input of nutrients is probably induced by three major factors: (i) saltwater intrusions into the system; (ii) river discharge and rainfall intensities, and (iii) agricultural and domestic input (CARMOUZE et al., 1991; KNOPPERS et al., 1999; KNOPPERS et al., 1991).

The margins of the lagoons are often colonized by the macrophyte Typha domingensis, a genus which is very common in coastal lagoons all over the world. This species usually dominates the community and tolerates polluted water conditions. In Brazil it is known as taboa and is a plant that typically creates transitional zones between continental areas and lagoons (MENDES et al., 2007).

\section{Experimental Design and Sample Collection}

The sampling design of this study has been created so that two of the four compartments of the lagoon system were chosen a priori: Maricá (M) and Guarapina $(\mathrm{G})$, representing the two extreme sectors of the lagoonal system, and distinguished for their position and connection to the ocean.

Two sampling sites were established for each compartment, according to the occurrence/absence - along the edges of the compartment - of vegetation (tagged as $\mathrm{V}=$ "vegetation" and NV= "absence of vegetation"). Vegetation, as mentioned above, is represented by the macrophyte T. domingensis. Samples were collected in January - February 2010, during the wet season (austral summer).

For the abiotic characterization, dissolved oxygen, temperature and salinity of the water column, and sediment Eh were measured in situ by using specific analytical probes and were taken once at each site. Sediment samples were taken randomly at all the sites in five replicates, using a $15 \mathrm{~cm}$ diameter corer, for analysis of macrozoobenthos. Additional sediment samples were collected in triplicate for grain size analysis. Total organic matter (TOM), $\mathrm{CaCO}_{3}$, chlorophyll- $a$ (Chl- $a$ ) and phaeopigment (Phaeo) concentrations were analysed in the first (top) centimeter of $10 \mathrm{~cm}$ diameter acrylic cores collected in triplicate at each site. Samples were stored in small black containers and immediately frozen for further analysis. Macrozoobenthos samples were processed in the field by washing them through a $0.5 \mathrm{~mm}$ mesh sieve, and the retained material was fixed in $4 \%$ formaldehyde for further laboratory qualification and quantification.

Regarding the stable carbon and nitrogen isotope analysis $\left(\delta^{13} \mathrm{C}\right.$ and $\left.\delta^{15} \mathrm{~N}\right)$, sediment samples and macrobenthos samples were collected, in order to obtain a general isotopic description to distinguish Maricá from Guarapina. Specimens were separated from sediment samples in the field (whenever possible), washed and frozen. Fishes were obtained 
with the aid of local fishermen in the Maricá compartment and, due to their mobility, they were considered representative of the whole compartment. Furthermore, potential primary food sources, such as macrophyte species and detritus (when present) were manually removed and washed in situ with distilled water and frozen for stable isotope analysis. Sediment and detritus samples were collected in triplicate at both sites in each compartment. T. domingensis was taken only when present, in the vegetated sites MV and GV.

\section{Laboratory Analysis}

\section{Sediment Features and Abiotic Data Analysis}

Grain size fractions were obtained in three replicates for each site, by mechanical dry sieving according to standard procedures. Since the very fine fraction of grains $(<1 \%)$ was not separated in this study, we have classified them them together as the silt-clay fraction. Sediments were classified according to their mean grain size and sorting index using Folk and Ward's (1957) statistics calculated with the aid of SYSGRAN 3.0 software (CAMARGO, 2006).

In order to determine total organic matter (TOM), a fraction of the sediment samples (five replicates for each site), of between 0.5 and $2.0 \mathrm{~g}$, was oven-dried at $60^{\circ} \mathrm{C}$ for 48 hours and burned in a Lavoisier oven at $495-500^{\circ} \mathrm{C}$ for two hours (byers et al., 1978). carbonate content was determined in three sub-samples of sediment for each site by digesting them with $10 \% \mathrm{HCl}$ for one hour.

For phytopigment quantification a method adapted from Plante-Cuny (1978) was followed. Pigments were extracted from $1.0-1.5 \mathrm{~g}$ of three samples for each site, with acetone $100 \%$ after refrigeration at a temperature between $4^{\circ} \mathrm{C}$ and $7^{\circ} \mathrm{C}$ for eighteen hours. The acetone extract was analyzed for chlorophyll- $a$ quantification by transferring it into a spectrophotometer cuvette of known pathlength (1 $\mathrm{cm})$. After rinsing the cuvette with some of the extract and then filling it with the extract, the sample was placed into the spectrophotometer $(665 \mathrm{~nm}$ and 750 $\mathrm{nm})$. After adding 1 drop of $1 \mathrm{M} \mathrm{HCl}$, the optical density was re-read at $665 \mathrm{~nm}$ and $750 \mathrm{~nm}$ for phaeopigment concentration. Concentrations of chlorophyll- $a$ and pheopigments $a$ were then calculated according to the equations given in Lorenzen (1967) and modified by Plante-Cuny (1974; 1978).

Macrozoobenthos Community

After being separated by sieving, organisms were preserved in $70 \%$ alcohol for quantification and taxonomic determination at the lowest possible taxonomic level by stereomicroscopy or frozen for further isotopic analysis. Organisms were grouped into trophic groups as carnivores, herbivores, detritivores, omnivores and planktivores (MORINO; ORTAL, 1995; PAMPLIN et al., 2007; JORGENSEN et al., 2009). Species abundances (mean) relative to core surface were calculated for each site.

\section{Stable Isotope Analysis}

Isotopic analyses were performed on only the macrozoobenthic species that reached the mass requirements for analytical determination. Analysis was carried out on white muscle tissue from fishes' dorsal region; on the pool of entire organisms, when considering small dimension fauna, such as polychates and amphipods; on muscle from three crabs' claws; on mature leaves of macrophytes; on detritus and sediment samples. Samples were thawed, washed with deionized water to leach inorganics for 30-60 minutes and oven dried at $60^{\circ} \mathrm{C}$ for 48 hours. Pools of organisms were rather freeze-dried using a lyophilizer. Fishes and crabs were dissected for tissues before being frozen. Amphipods were acidified ( $\mathrm{HCl} 1 \mathrm{M})$ before drying. The presence of carbonates in marine organisms can, in fact, alter the carbon isotopic signatures. For this reason, their elimination through acidification with $\mathrm{HCl}$ is necessary especially when, due to the small size of the individuals, it is not possible to remove the carbonated structures (CARABEL et al., 2006). Samples were ground to fine powder using a mortar and pestle, stored at room temperature and packed into tin capsules. Stable isotope measurement involved complete conversion of the sample into a gas $\left(\mathrm{CO}_{2}\right.$ and $\left.\mathrm{N}_{2}\right)$ by combustion and separation of pure gases in an elemental analyser (Thermo Scientific EA 1112). The pure gas was then introduced into an isotope ratio mass spectrometer (Thermo Scientific, DeltaPlus XP), and the isotopic composition was quantified relative to a standard reference material.

The resulting stable isotope abundances are expressed as the ratio of the two most abundant isotopes in the sample compared to the same ratio in an international standard, using the 'delta' $(\delta)$ notation that is $\delta \mathrm{X}$ (where $\mathrm{X}$ represents the heavier isotope ${ }^{13} \mathrm{C}$ or ${ }^{15} \mathrm{~N}$ ). Because the differences in ratios between the sample and standard are very small, they are expressed as parts per thousand or 'per mil' (\%o) deviation from the standard and are calculated according to the following formula:

$\delta \mathrm{X}=[($ Rsample $/$ Rstandard $)-1] \times 10^{3}$

where:

Rsample $={ }^{13} \mathrm{C} /{ }^{12} \mathrm{C}$ or ${ }^{15} \mathrm{~N} /{ }^{14} \mathrm{~N}$ of the sample Rstandard $={ }^{13} \mathrm{C} /{ }^{12} \mathrm{C}$ or ${ }^{15} \mathrm{~N} /{ }^{14} \mathrm{~N}$ of the standard 


\section{Data Analysis}

A Principal Component Analysis (PCA) was performed for $\log (\mathrm{X}+1)$ or to arcsin (for percentage data) and normalized abiotic data as exploratory analysis.

Abiotic data were also analysed by twofactor PERMANOVA, Permutational Multivariate Analysis of Variance (ANDERSON, 2001), in order to assess whether there were differences between sites or compartments and to test the hypothesis that the vegetation has an effect on these differences. Abiotic data were normalized and resembled on Euclidean distance. The two factors considered were Compartment (with two levels: Maricá versus Guarapina - fixed) and Vegetation (two levels: presence and absence of vegetation - fixed).

All statistical analyses were performed using PRIMER 6 (version 6.1.11) \& PERMANOVA+ (version 1.0.1).

Macrobenthic community structure was characterized by the total number of species (S), total number of individuals $(\mathrm{N})$, and Shannon-Wiener diversity (H'). In order to visually examine patterns of similarity between compartments and between sites, biotic data were analyzed after square root transformation using non-metric multi-dimensionalscaling (nMDS) based on the Bray-Curtis similarity index. SIMPER analysis (CLARKE, 1993) was performed to determine the contribution of each species to the average resemblances between sample groups.

A multivariate correlation, BIOENV, was used to confirm visual patterns and to correlate species abundances with abiotic parameters, quantitatively exploring the relationship between levels of different factors and biotic patterns (CLARKE \& WARWICK, 2001). BIOENV was performed calculating Euclidean distances of the abiotic dataset and using the rank correlation method of Spearman.

As regards stable isotope data, carbon and nitrogen isotopic signatures from the different consumers were related to potential sources of organic matter through the use of scatter plots.

\section{RESULTS}

\section{Environmental characterization}

Salinity in each compartment had a distinct range, in Maricá (M) from 6 to 10 (PSU) and in Guarapina (G) from 20 to 21 . Redox potential (Eh) was negative at all the sites in both compartments, indicating an anaerobic condition. In $\mathrm{G}$ it ranged from $-255 \mathrm{mV}$ to $-272 \mathrm{mV}$, whereas in $\mathrm{M}$ from $-161 \mathrm{mV}$ and $-133 \mathrm{mV}$. Dissolved oxygen was very similar at both vegetated (MV) and non-vegetated (MNV) sites of Maricá compartment, $7.3 \mathrm{mg} \mathrm{L}^{-1} 1$ and $7.8 \mathrm{mg} \mathrm{L}^{-1}$ respectively. In $\mathrm{G}$, dissolved oxygen differed at the two sites, $15.2 \mathrm{mg} \mathrm{L}^{-1}$ in the GNV and $20.5 \mathrm{mg} \mathrm{L}^{-1}$ in $\mathrm{GV}$. Water temperature in $\mathrm{M}$ at the moment of sampling ranged from $34.6{ }^{\circ} \mathrm{C}$ to $35.2{ }^{\circ} \mathrm{C}$ and in $\mathrm{G}$ from $32.2^{\circ} \mathrm{C}$ to $37.7^{\circ} \mathrm{C}$.

Granulometric analyses allowed us to classify the sediment according to the mean size and to the sorting index as well sorted and poorly sorted (Table 1). All M replicates showed a poorly sorted sediment $(1.3 \varphi-1.7 \varphi)$, whereas G's were well sorted $(0.35 \varphi-0.50 \varphi)$. There was a predominance of sand over gravel and silt-clay fractions in both compartments.

Table 1. Classification of sediment according to mean size and to the sorting index $(\varphi)$.

\begin{tabular}{llrcrl}
\hline \hline \multicolumn{1}{c}{ site } & mean size & & $\varphi$ & & classification \\
\hline & mean & sd & mean & sd & \\
\hline MV & 1.30 & 0.40 & 1.57 & 0.07 & poorly sorted \\
MNV & 0.57 & 0.30 & 1.39 & 0.14 & poorly sorted \\
GV & 1.09 & 0.04 & 0.46 & 0.03 & well sorted \\
GNV & 1.10 & 0.05 & 0.40 & 0.02 & well sorted \\
\hline
\end{tabular}

Organic matter concentration (Table 2) was higher in both MV (5.12\%) and GV (1.15\%), with an evidently higher organic matter percentage in $\mathrm{M}$ $(3.66 \%)$ than in $\mathrm{G}(0.92 \%)$ sites.

Carbonate percentage showed differences within compartments. MV showed higher values, whereas $\mathrm{G}$, presenting higher values than $\mathrm{M}$, showed the opposite result (Table 2).

Chlorophyll- $a$ concentration was low, always below $10 \mu \mathrm{g} \mathrm{g}^{-1}$. However, in the $\mathrm{GV}$ the concentration was as high as $49.6 \pm 2.1 \mu \mathrm{g} \mathrm{g}^{-1}$, whereas in GNV the concentration was lower $\left(3.4 \pm 3.6 \mu \mathrm{g} \mathrm{g}^{-1}\right)$. $\mathrm{MV}$, on the contrary, presented on average a low chlorophyll- $a$ concentration value of $\sim 8.5 \pm 0.3 \mu \mathrm{g} \mathrm{g}^{-1}$. Moreover, phaeopigment concentrations followed the Chl- $a$ trend, with highest values on average at both vegetated sites MV and GV. Chl- $a$ to Phaeopigment ratio was calculated. Ratio values lower than 1 were found only in GNV, whereas site GV showed higher values, along with both MV and MNV (Table 2).

Table 2. Organic matter, Carbonate, Chlorophyll- $a$ and Phaeopigment concentration for each site. $\mathrm{M}=$ Marica; $\mathrm{G}=$ Guarapina; $\mathrm{V}=$ vegeted; $\mathrm{NV}=$ non vegetated.

\begin{tabular}{lllll}
\hline \hline & MV & MNV & GV & GNV \\
\hline Organic Matter $(\%)$ & 5.10 & 2.22 & 0.69 & 1.15 \\
Carbonate $(\%)$ & 5.71 & 1.02 & 7.09 & 2.60 \\
Chlorophyll- $a\left(\mu \mathrm{g} \mathrm{g}^{-1}\right)$ & 8.52 & 3.17 & 3.39 & 49.64 \\
Phaeopigments $\left(\mu \mathrm{g} \mathrm{g}^{-1}\right)$ & 8.64 & 3.25 & 16.14 & 41.12 \\
\hline
\end{tabular}


The results of PERMANOVA showed a significant interaction between factors Compartment and Vegetation (Compartment $\mathrm{xVegetation),} \mathrm{with} \mathrm{a} \mathrm{P}<$ $0.05(\mathrm{P}(\mathrm{MC})=0.037)$ (Table 3). Principal Component Analysis of abiotic parameters showed that the joint input of the first two axes explained $\sim 72 \%$ of the total variance (Fig. 2). PC-1 accounted for most of the variance $(\sim 56 \%)$. The PCA showed the separation of environmental response in two groups of samples. There was, in fact, an evident distinction between the $\mathrm{M}$ and $\mathrm{G}$ samples. Moreover, there was a grouping of samples belonging to site MV and MNV. Sample grouping on the first axis of PC-1 was due to Chlorophyll- $a$, Phaeopigments and sand versus rubble, sorting index and silt+clay components. Along the PC2 axis, the grouping is due to the carbonate percentage $\left(\% \mathrm{CaCO}_{3}\right)$. Organic matter seems to have an influence both on the PC-1 axis and on the PC-2 one variability. Nearly all G samples follow the direction of increasing Chlorophyll-a. Moreover, sediment characteristics seem to have an influence on the sample groupings, with an evident discrimination between rubble type of sediment and sand.

\section{Macrozoobenthos}

A total of 909 individuals were collected, of which 610 at sites MV and MNV, and 299 at GNV while at GV no specimen was found (Table 4).

Only nine taxa were recovered from the four sampling sites and the corresponding twenty replicates. Mollusk Heleobia australis and polychaete Laeonereis culveri were the dominant species at MV $(67 \%)$ and MNV (28\%) sites, respectively, whereas polychaete Capitella $c f$. capitata $(58 \%)$ dominated at site GV.

Table 3. Permanova results of abiotic data.

\begin{tabular}{lllllll}
\hline \hline Source & df & MS & Pseudo-F & P(perm) & perms & P(MC) \\
\hline Compartment & 1 & 47,506 & 17,548 & 0.002 & 987 & 0.001 \\
Vegetation & 1 & 9,646 & 3,563 & 0.006 & 977 & 0.019 \\
Comp x Vegetation & 1 & 9,189 & 3,394 & 0.006 & 986 & 0.037 \\
Residuals & 8 & 2,707 & & & & \\
\hline
\end{tabular}

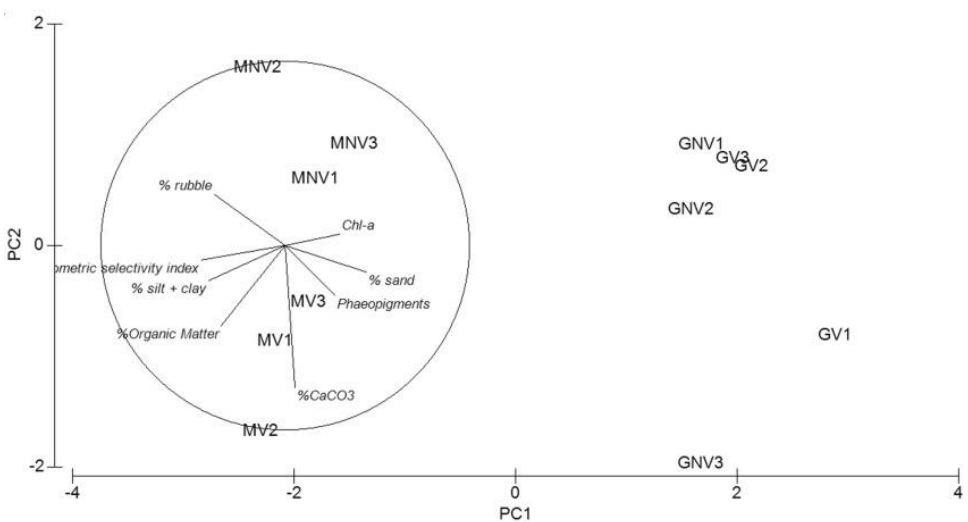

Fig. 2. Principal Component Analysis (PCA) of abiotic data. MV: Maricà with vegetation; MNV: Maricà without vegetation; GV: Guarapina with vegetation; GNV: Guarapina without vegetation.

Table 4. Species abundances (mean) relative to core surface for each site.

\begin{tabular}{|c|c|c|c|c|c|c|c|c|c|}
\hline & $\begin{array}{c}\text { Mollusca } \\
\text { H. australis }\end{array}$ & $\begin{array}{c}\text { Crustacea } \\
\text { Podocopida } \\
\text { sp. }\end{array}$ & $\begin{array}{l}\text { Polychaeta } \\
\text { L. culveri }\end{array}$ & $\begin{array}{l}\text { Polychaeta } \\
\text { A. succinea }\end{array}$ & $\begin{array}{c}\text { Polychaeta } \\
\text { S. cf. benedictii }\end{array}$ & $\begin{array}{l}\text { Polychaeta } \\
\text { Polydora sp. }\end{array}$ & $\begin{array}{c}\text { Polychaeta } \\
\text { C. cf. capitata }\end{array}$ & $\begin{array}{c}\text { Polychaeta } \\
\text { S. grubii }\end{array}$ & Oligochaeta \\
\hline MV & 41.6 & 6.6 & 2.2 & 0 & 1.8 & 0 & 3.6 & 0 & 6.0 \\
\hline MNV & 11.4 & 3.6 & 6.6 & 0 & 6.6 & 0.6 & 14.2 & 0 & 17.2 \\
\hline GV & 0 & 0 & 0 & 0 & 0 & 0 & 0 & 0 & 0 \\
\hline GNV & 0.4 & 1.0 & 1.2 & 0.8 & 2.2 & 0 & 34.6 & 0.8 & 18.8 \\
\hline
\end{tabular}


The highest number of species was found in MNV (6.0 \pm 0.5$)$, whereas the lowest number of species was found in $\mathrm{MV}(\mathrm{S}=5.2 \pm 0.4)$ (see table 5). The Shannon-Wiener diversity ranged from 1.1 to 1.5 for $\mathrm{M}$ and from 0.0 to 1.1 for $\mathrm{G}$, increasing as the number of species increases, as one would expect.

Table 5. Summary of community descriptors at each site (S: total species. N: total individuals, H': Shannon-Wiener diversity index).

\begin{tabular}{lllllll}
\hline \hline Site & \multicolumn{2}{c}{ S } & \multicolumn{2}{c}{ N } & \multicolumn{2}{c}{ H'$^{\prime}$} \\
\hline & mean & se & mean & se & mean & se \\
\hline MV & 5.2 & 0.4 & 60.8 & 26.3 & 1.1 & 0.1 \\
MNV & 6.0 & 0.5 & 60.0 & 11.8 & 1.5 & 0.1 \\
GV & 0.0 & 0.0 & 0.0 & 0.0 & 0.0 & 0.0 \\
GNV & 5.0 & 0.5 & 60.4 & 19.8 & 1.1 & 0.1
\end{tabular}

The SIMPER analysis (Table 6) showed that the taxa which most influenced the dissimilarity between $\mathrm{M}$ and $\mathrm{G}$ were the mollusk Heleobia australis (Contrib\%=26.14), the polychaete Capitella $c f$. capitata $\quad($ Contrib\%=20.49) and Oligochaeta (Contrib\%=13.08).

Average dissimilarity between sites MV and MNV was given by Heleobia australis (Contrib\%=26.12), Capitella cf. capitata $($ Contrib\% $=16.65)$ and Oligochaeta $($ Contrib\%=15.78). On the other hand, the same taxa influenced the average dissimilarity between sites MV/GNV and MNV/GNV.
The ordination analysis MDS showed that the macrobenthos community was well structured throughout the lagoonal system, with marked differences among $\mathrm{M}$ and $\mathrm{G}$ sites. Because of the absence of organisms in GV, we have added a constant of 0.1 to the whole set of data, obtaining the same MDS distribution (Fig. 3) as that from which the $\mathrm{GV}$ data were excluded (all being equal to zero).

The results of Biota and Enviromental matching analysis (BioEnv) showed that the best correlation coefficients were given by Chlorophyll- $a$, phaeopigments, organic matter and sorting coefficient (Table 7). Rank correlations between the MDS and PCA ordinations were obtained from various combinations of the normalized environmental variables.

\section{Stable Isotope Analysis}

The potential organic matter sources collected in the Maricá-Guarapina lagoon system were, when present, the macrophyta $T$. domingensis, detritus and sedimentary organic matter. As derived from microscope observations and from the $\mathrm{C} / \mathrm{N}$ ratios (Table 8), detritus seemed to derive mostly from terrestrial vegetation ( $T$. domingensis) and to a lesser extent from aquatic vegetation, such as macroalgae and marginal seagrasses.

Table 6. Summary of SIMPER analysis. Abbreviations in Fig. 2.

\begin{tabular}{|c|c|c|c|c|c|c|c|c|c|}
\hline \multirow[t]{2}{*}{ Taxa } & \multicolumn{3}{|c|}{$\begin{array}{c}\text { MV \& MNV } \\
\text { average dissimilarity }=40,48\end{array}$} & \multicolumn{3}{|c|}{$\begin{array}{c}\text { MV \& GNV } \\
\text { average dissimilarity }=56,02\end{array}$} & \multicolumn{3}{|c|}{$\begin{array}{c}\text { MNV \& GNV } \\
\text { average dissimilarity }=43,40\end{array}$} \\
\hline & $\begin{array}{c}\text { Av.Abun. } \\
\text { MV }\end{array}$ & $\begin{array}{l}\text { Av. Abun. } \\
\text { MNV }\end{array}$ & $\mathrm{C}(\%)$ & $\begin{array}{c}\text { Av.Abun. } \\
\text { MV }\end{array}$ & Av.Abun.GNV & $\mathrm{C}(\%)$ & $\begin{array}{l}\text { Av.Abun. } \\
\text { MNV }\end{array}$ & Av.Abun.GNV & $\mathrm{C}(\%)$ \\
\hline $\begin{array}{l}\text { Heleobia } \\
\text { australis }\end{array}$ & 5.18 & 3.23 & 26.12 & 5.18 & 0.40 & 29.27 & 3.23 & 0,40 & 22,10 \\
\hline $\begin{array}{l}\text { Capitella } \mathrm{cf} . \\
\text { capitata }\end{array}$ & 1.73 & 3.65 & 15.78 & 1.30 & 0.80 & 24.02 & 3.78 & 4,11 & 15,93 \\
\hline Oligochaeta & 1.09 & 2.44 & 16.65 & 2.35 & 4.11 & 12.31 & 3.65 & 5,47 & 14,08 \\
\hline Podocopida & 2.14 & 1.49 & 13.13 & 2.14 & 0.60 & 11.64 & 1.49 & 0,60 & 9,14 \\
\hline $\begin{array}{l}\text { Laeonereis } \\
\text { culveri }\end{array}$ & 1.30 & 2.24 & 12.59 & 1.73 & 5.47 & 6.63 & 2.24 & 0,80 & 13,25 \\
\hline $\begin{array}{l}\text { Streblospio cf. } \\
\text { benedictii }\end{array}$ & 2.35 & 3.78 & 11.90 & 1.09 & 1.12 & 6.80 & 2.44 & 1,12 & 11,52 \\
\hline
\end{tabular}

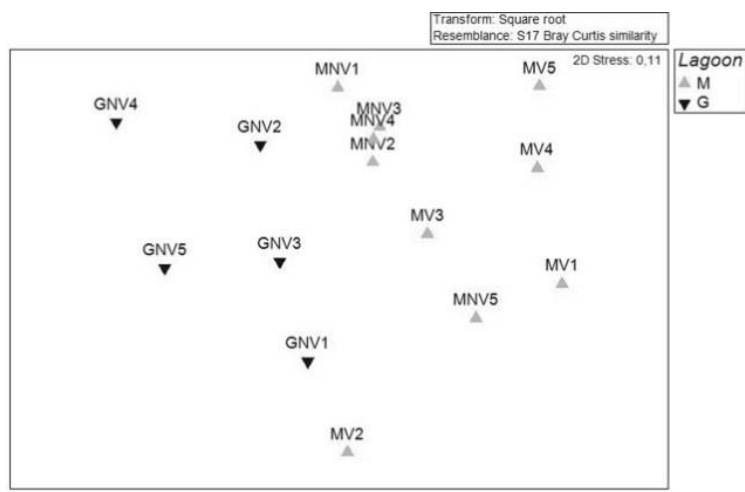

Fig. 3. MDS analysis. MV: Maricà with vegetation; MNV Maricà without vegetation; GV: Guarapina with vegetation; GNV: Guarapina without vegetation. 
Table 7. Summary of Environmental matching analysis (BioEnv).

\begin{tabular}{lc}
\hline \hline Environmental variables & Sample statistic (Rho) \\
\hline Chl- $a$ & 0.826 \\
Phaeopigments, \% Organic matter & 0.793 \\
Selectivity Index, Chl- $a$ & 0.776 \\
\hline
\end{tabular}

In the compartment of Maricá, in both sites MV and MNV, it is possible to assess that detritus and sedimentary organic matter were more enriched than T. domingensis $\left(\delta^{13} \mathrm{C}=-29.97 \pm 0.12 \%\right.$ ) (Table 9$)$. The isotopic composition of detritus is more enriched in the Maricá site MV $\left(\delta^{13} \mathrm{C}=-19.44 \pm 0.93 \%\right.$ ) than in the Guarapina $\mathrm{GV} \quad\left(\delta^{13} \mathrm{C}=-26.22 \pm 1.00 \%\right.$ ), and more depleted in the MNV site $\left(\delta^{13} \mathrm{C}=-28.01 \pm 0.64 \%\right)$ than in GNV $(-25.51 \pm 1.35 \%)$; this consideration cannot be made for the sedimentary organic matter samples or the $T$. domingensis vegetation, since in the Guarapina compartment these potential basal sources present more ${ }^{13} \mathrm{C}$-enriched values.

In Maricá $\delta^{13} \mathrm{C}$ showed less variability in the organic matter sources than in consumers which ranged from about $-26.4 \%$ in Micropogonias furnieri to $-13.4 \%$ in Albula vulpes. In Guarapina, on the other hand, $\delta^{13} \mathrm{C}$ signatures varied greatly in the organic matter sources ranging from $-29.52 \pm 0.04 \%$ in $T$. domingensis to $-16.75 \pm 0.05 \%$ at site GNV for the sedimentary organic matter. Few consumers were collected in this compartment and their $\delta^{13} \mathrm{C}$ signatures varied greatly from those of $T$. domingensis and detritus, being closer to the sedimentary organic matter values. We may, further, say that overall the only consumer analysed in both compartments (Laeonereis culveri) showed much more ${ }^{13} \mathrm{C}$-depleted values in Maricá (MV=-26.28\%o; $M N V=-2.92 \%$ ) than in Guarapina (GNV=-21.4\%o).

There is a variation between $\delta^{15} \mathrm{~N}$ signatures of organic matter sources and consumers in both compartments, in agreement with the expected isotopic enrichment for each trophic level (POST, 2002). Overall, in regard to the organic matter sources, in Guarapina the most enriched value of $\delta^{15} \mathrm{~N}$ was exhibited by $T$. domingensis $(5.04 \pm 0.08 \%)$ and the lowest by the detritus in Guarapina GNV (3.53 $\pm 0.11 \%$ ); in Maricá, on the other hand, the most enriched value of $\delta^{15} \mathrm{~N}$ was exhibited by the detritus
$(5.28 \pm 0.63 \%)$ and the least by the detritus at the nonvegetated site $(1.43 \pm 9.47 \%)$. Among the consumers in Maricá, Brevoortia pectinata has the highest value (14.9\%o), whereas Callinictes danae, Platorchestia monodi and Mugil curema have the lowest (8.1\%o, $6.7 \%$ and $6.7 \%$ respectively).

In Guarapina, L. culveri exhibited a low value $(5.7 \%$ o vs. $10.5 \pm 0.3 \%$ of for the same taxon in Maricá), while the other consumer analysed, Farfantepenaeus paulensis, had much higher values $(9.2 \pm 2.1 \%)$.

\section{DisCUSSION}

Coastal lagoons are generally characterised by large fluctuations in environmental variables due to the intermittent entrance of both seawater and freshwater and these fluctuations may cause changes in the structure and distribution pattern of organisms (MARZANO et al., 2010).

Abiotic data showed differences in the lagoon system studied between the two compartments of Maricá and Guarapina. The first compartment, Maricá, is an inner sector not subject to tidal influence, having low salinity and a high organic matter load. Chlorophyll- $a$ and phaeopigments show lower values than in Guarapina. This second compartment, subject to tidal influence due to its direct connection to the sea, presents higher salinity values, lower organic matter concentration and higher chlorophyll- $a$ and phaeopigment concentrations. Phaeopigments are degradation products of chlorophyll, produced as the chlorophyll molecules within algal cells are degraded. The high concentration of chlorophyll- $a$ detected in Guarapina compartment could derive from its proximity to the sea and could thereby arise either from the sedimentation of fresh phytoplankton cells or the presence of microphytobenthos in the sediment. Chl- $a /$ Phaeo ratios $<1$, as shown at the non-vegetated site of Guarapina, may suggest a high input of detritus and partially degraded organic matter (CADÉE; HEGEMAN, 1974). Chl- $a$ /Phaeo ratios $>1$, found at all the sites in Maricá and at the vegetated site of Guarapina, suggest that chlorophyll- $a$ was the most abundant pigment.

Table 8. C/N ratios for samples taken in Maricá (M) and Guarapina (G).

\begin{tabular}{llllllll}
\hline \hline Sample & Type & \%N & & \%C & & $\begin{array}{l}\text { C/N } \\
\text { ratio }\end{array}$ & \\
\hline & & mean & sd & mean & sd & mean & sd \\
\hline MV & detritus & 0.65 & 0.02 & 15.54 & 0.93 & 23,81 & 1,20 \\
MNV & detritus & 1.38 & 0.14 & 36.70 & 0.81 & 26,66 & 2,14 \\
GV & detritus & 1.29 & 0.08 & 36.18 & 0.27 & 29,61 & 2,07 \\
GNV & detritus & 1.34 & 0.2 & 36.12 & 2.61 & 27,23 & 2,92 \\
MV & Typha & 1.82 & 0.11 & 38.60 & 3.35 & 21,25 & 0,53 \\
GV & Typha & 1.70 & 0.08 & 40.43 & 2.02 & 23,83 & 0,10 \\
MV & SOM & 0.05 & 0.00 & 0.39 & 0.02 & 8.21 & 0.48 \\
MNV & SOM & 0.05 & 0.02 & 0.40 & 0.16 & 0,36 & 0,05 \\
GV & SOM & 0.02 & 0.01 & 0.11 & 0.07 & 0,24 & 0,10 \\
GNV & SOM & 0.02 & 0.00 & 0.11 & 0.02 & 0,27 & 0,05 \\
\hline
\end{tabular}


Table 9. Stable Isotope data for organic matter sources and invertebrates in the Maricá and Guarapina compartments. V = vegetated; $\mathrm{NV}=$ non vegetated.

\begin{tabular}{|c|c|c|c|c|c|c|c|c|c|c|c|c|c|c|c|c|}
\hline & \multicolumn{4}{|c|}{ MV } & \multicolumn{4}{|c|}{ MNV } & \multicolumn{4}{|c|}{ GV } & \multicolumn{4}{|c|}{ GNV } \\
\hline & $\delta^{13} \mathrm{C}$ & & $\delta^{15} \mathrm{~N}$ & & $\delta^{13} \mathrm{C}$ & & $\delta^{15} \mathrm{~N}$ & & $\delta^{13} \mathrm{C}$ & & $\delta^{15} \mathrm{~N}$ & & $\delta^{13} \mathrm{C}$ & & $\delta^{15} \mathrm{~N}$ & \\
\hline & mean & sd & mean & sd & mean & sd & mean & $\mathrm{sd}$ & mean & sd & mean & $\mathrm{sd}$ & mean & $\mathrm{sd}$ & mean & sd \\
\hline \multicolumn{17}{|l|}{$\begin{array}{l}\text { Organic matter } \\
\text { sources }\end{array}$} \\
\hline Detritus & $-19,4$ & 0,93 & 5,28 & 0,63 & -28 & 0,64 & 1,43 & 0,47 & $-26,2$ & 1 & 4,07 & 0,43 & $-25,5$ & 1,35 & 3,53 & $0,11-$ \\
\hline $\begin{array}{l}\text { Typha } \\
\text { domingensis }\end{array}$ & -30.0 & 0,12 & 4,98 & 0,55 & - & - & - & - & $-29,5$ & 0,04 & 5,04 & 0,08 & - & - & - & - \\
\hline $\begin{array}{l}\text { Sedimentary } \\
\text { organic matter }\end{array}$ & $-23,5$ & 0,13 & 4,98 & 0,07 & $-23,5$ & 0,15 & 5,07 & 0,34 & $-20,3$ & 0,25 & 4,6 & 0,52 & $-16,8$ & 0,05 & 4,39 & 0,18 \\
\hline \multicolumn{17}{|l|}{ Invertebrates } \\
\hline $\begin{array}{l}\text { Callinictes } \\
\text { danae }\end{array}$ & $-18,7$ & - & 8,06 & - & & & & & & & & & & & & \\
\hline \multicolumn{17}{|l|}{$\begin{array}{l}\text { (Decapoda, } \\
\text { Portunidae) }\end{array}$} \\
\hline $\begin{array}{l}\text { Callinictes } \\
\text { sapidus }\end{array}$ & $-22,5$ & - & 12,14 & - & & & & & & & & & & & & \\
\hline \multicolumn{17}{|l|}{$\begin{array}{l}\text { (Decapoda, } \\
\text { Portunidae) }\end{array}$} \\
\hline \multicolumn{17}{|c|}{ (Decapoda Penaeidae) } \\
\hline \multicolumn{17}{|l|}{$\begin{array}{l}\text { (Polychaeta } \\
\text { Capitellidae) }\end{array}$} \\
\hline $\begin{array}{l}\text { Laeonereis culveri } \\
\text { (Polychaeta } \\
\text { Nereidae) }\end{array}$ & $\begin{array}{l}- \\
26, \\
3\end{array}$ & - & 10,7 & - & $-25,9$ & - & 10,29 & - & & & & & $-21,4$ & - & 5,7 & - \\
\hline $\begin{array}{l}\text { Platorchestia } \\
\text { monodi }\end{array}$ & & & & & $-20,8$ & - & 6,71 & - & & & & & & & & \\
\hline $\begin{array}{l}\text { (Amphipoda } \\
\text { Talitridae) }\end{array}$ & & & & & & & & & & & & & & & & \\
\hline
\end{tabular}

Table 10. Fish stable isotopes for the compartment of Maricá (family is reported in brackets).

\begin{tabular}{lllll}
\hline \hline & \multicolumn{4}{l}{ MV and MNV } \\
\hline & $\delta^{13} \mathrm{C}$ & & \multicolumn{3}{l}{$\delta^{15} \mathrm{~N}$} & \\
\hline & mean & sd & mean & sd \\
\hline Albula vulpes(Albulidae) & -13.35 & - & 11,62 & - \\
Anchoa sp. (Engraulida) & -19.16 & - & 10,65 & - \\
Atherinella brasiliensis(Atherinopsidae) & -22.57 & - & 14,11 & - \\
Brevoortia pectinata (Clupeidae) & -26.14 & - & 14,86 & - \\
Characidae & -19.53 & - & 9,63 & - \\
Caranx sp. (Carangidae) & -22.51 & - & 14,65 & - \\
Eucinostomus sp. (Gerreidae) & -22.75 & - & 13,16 & - \\
Hexanematichthys grandoculis(Ariidae) & -19.98 & - & 10,68 & - \\
Micropogonias turneri (Sciaenidae) & -26.41 & - & 12,36 & - \\
Mugil sp. (Mugilidae) & -19.14 & - & 8,02 & - \\
Mugil curema (Mugilidae) & -16.33 & - & 6,69 & - \\
Netuma barba (Ariidae) & -22.96 & - & 13,52 & - \\
\hline
\end{tabular}

Typha domingensis seems not to influence parameters such $\mathrm{s}$ carbonate and organic matter percentages. In fact, although a difference within compartments has been highlighted, in neither case does this discrimination follow a trend nor does it correspond at the two sites. We may state, more specifically, that the vegetated site of Maricá presents higher values of carbonate concentration than does the non-vegetated one; whereas the opposite situation was revealed by the results obtained for Guarapina. Organic matter percentage, on the other hand, is higher at both vegetated sites in either compartments, but in Guarapina there is only a slight difference that may be considered negligible. 
The composition of macrozoobenthic fauna in the Maricá-Guarapina lagoon system is still largely unknown. In fact this study represents one of the first attempts to characterise this environment. Most species found in the Maricá-Guarapina lagoon system are common also to those sampled in other systems along the coast of the Fluminense area of Rio de Janeiro State, the low richness (S) also being frequent (GOMES et al., 2000; MENDES et al., 2007). The numerically dominant species in this study such as the polychaets $C$. $\quad c f$. capitata, $L$. culveri and oligochaetaes, are opportunistic. Usually polichaetaes such as the Capitellidae are the most abundant taxonomic group in lagoons with urban influence or in organically polluted areas (MIKAC et al., 2007). The gastropod $H$. australis has the highest occurrence in the lagoon and is the dominant species of the Hydrobiidae family in South America, occurring in estuarine systems and coastal lagoons from Rio de Janeiro, Brazil to the Rio Negro, Argentina (NEVES et al., 2010). This species seems to be related to low dissolved oxygen concentration and in this study it was in fact collected mostly at the vegetated site of Maricá, which shows the lowest dissolved oxygen values.

According to Marzano et al. (2010), some biogeographical regions can share species, forming a typical stock of them; moreover, the recent origin of the majority of brackish biotopes lies at the root of the paucity of species and uniformity of their fauna from a macroscopic point of view.

The macrozoobenthos assemblages are, in both compartments, very poor and the number of individuals $(\mathrm{N})$ and number of species $(\mathrm{S})$ is always very low within sites. This result corroborates those of other studies on coastal lagoons in the Fluminense area where this same paucity of number of species has also been reported (FIGUEIREDO-BARROS et al., 2006; GOMES et al., 2009).

As far as numbers of species are concerned, no evident difference between Maricá and Guarapina was detected. However, the Guarapina compartment differed from that of Maricá regarding the prevalence of polychaete $C$. $c f$. capitata over mollusc $H$. australis. Such differences can be explained, not only as being due to different abiotic characteristics, but also in terms of the different adaptability and colonization strategies of the various species (MARZANO et al., 2010). Many polychaete species are opportunistic and of small size and can rapidly increase or decrease in density in response to biotic and abiotic disturbances (GIANGRANDE \& FRASCHETTI, 1996). A further example is represented by polychaete $C$. $c f$. capitata, which does not tolerate low salinity values (below $20 \mathrm{ppm}$ ). Salinity, along with stressed confinement (the time of renewal of components of marine origin at a given location), determine species distribution and biological zonation of benthic communities in lagoon ecosystems (PERTHUISOT; GUELORGET, 1983; LARDICCI et al., 1997; MARZANO et al., 2010). Moreover, molluscs predominate in areas with coarse sediments (MILLET \& GUELORGET, 1994) and granulometric analyses confirm the presence of $H$. australis at Maricá sites where, although sand is the dominant component of the sediment, there is also a good percentage of gravel.

No distinction could be drawn between vegetated sites and non-vegetated sites, except in the case of Guarapina. Indeed the presence of vegetation was coupled with an absence of macrozoobenthos. In Maricá $T$. domingensis does not seem to exercise any influence on abundances, whereas slight differences were observed for the number of species in this compartment, being on average five and six species at the vegetated and non-vegetated sites, respectively. Furthermore, the dramatically reduced number of species (and organisms) at the vegetated site of Guarapina has also occurred in other lagoons such as Lagoa De Araruama, one of the largest lagoons in Brazil, in the Fluminense area (SILVA et al., 2005). This result, however, does not show conclusively that disturbances due to human activities have caused the patterns; it could turn out to be a specific event due to the sampling site's characteristics.

Sediment abiotic variables may influence the distribution of macrobenthos and thus contribute to the contrast between Maricá and Guarapina. The sorting coefficient of sediment grain sizes could be viewed as a measure of spatial heterogeneity (SILVA et al., 2005) meaning that to higher values of this coefficient corresponds a more heterogeneous environment. Thus, as Maricá is the compartment with a higher sorting coefficient of sediment grain size (selectivity index result was poorly sorted), what was to be expected has been confirmed: a more heterogeneous habitat with a macrobenthic fauna consequently different from Guarapina's. However, although grain size is usually reported as the main factor influencing the distribution of benthos, there is little cause-effect evidence of the relationship of grain size per se to benthic distribution, as has been highlighted by Snelgrove; Butman (1994). Besides granulometric features, the organic matter in the sediment may influence the macrobenthos along with freshwater supplies from rivers or anthropogenic inputs. Lindegarth and Hoskin (2001) proved that differences among sites could be caused by sediment associated factors and organic content, which, as in our lagoon system, appears to be greater at the sites in Maricá.

The BIOENV results suggest that, in the two compartments studied, the composition of benthic communities appears to be mainly influenced by 
abiotic factors, such as chlorophyll- $a$, sediment analysis and organic matter concentration, that usually influence other lagoon systems.

The interaction between environmental variables did not identify any one particular factor that could be responsible for the observed faunistic pattern. According to Lardicci et al. (1993) who stated that biotic zonation cannot be explained by a single major factor, even in environments such as brackish habitats, it would be more reliable to take into account both the synergism among abiotic factors and the influence of biotic interactions.

The results of the analysis of the stable isotope ratios are indicative of the fact that consumers seem to be subject to different organic matter inputs (Fig. 4).
In Maricá the isotopic composition of consumers may allow us to distinguish three groups. The first one includes consumers belonging to Nereididae polychaetaes, the fish Brevoortia pectiniata and Micropogonias furnieri - and more specifically, based on literature data (MAZURKIEWICZ, 1975) and isotopic signatures, $L$. culveri, which is a non-selective deposit feeder. $B$. pectinata is acknowledged to be a planktivorous feeder (NAKAMURA et al., 1986). Although no zooplankton was collected in the present study, the isotopic composition of $B$. pectinata is compatible with the exploitation of zooplankton as its isotopic composition is generally in the range of $-17 \%$ and $26 \%$ for $\delta^{13} \mathrm{C}$ and about $9.0 \pm 2 \%$ or for $\delta^{15} \mathrm{~N}$ (VIZZINI; MAZZOLA, 2003, VIZZINI et al., 2005a).
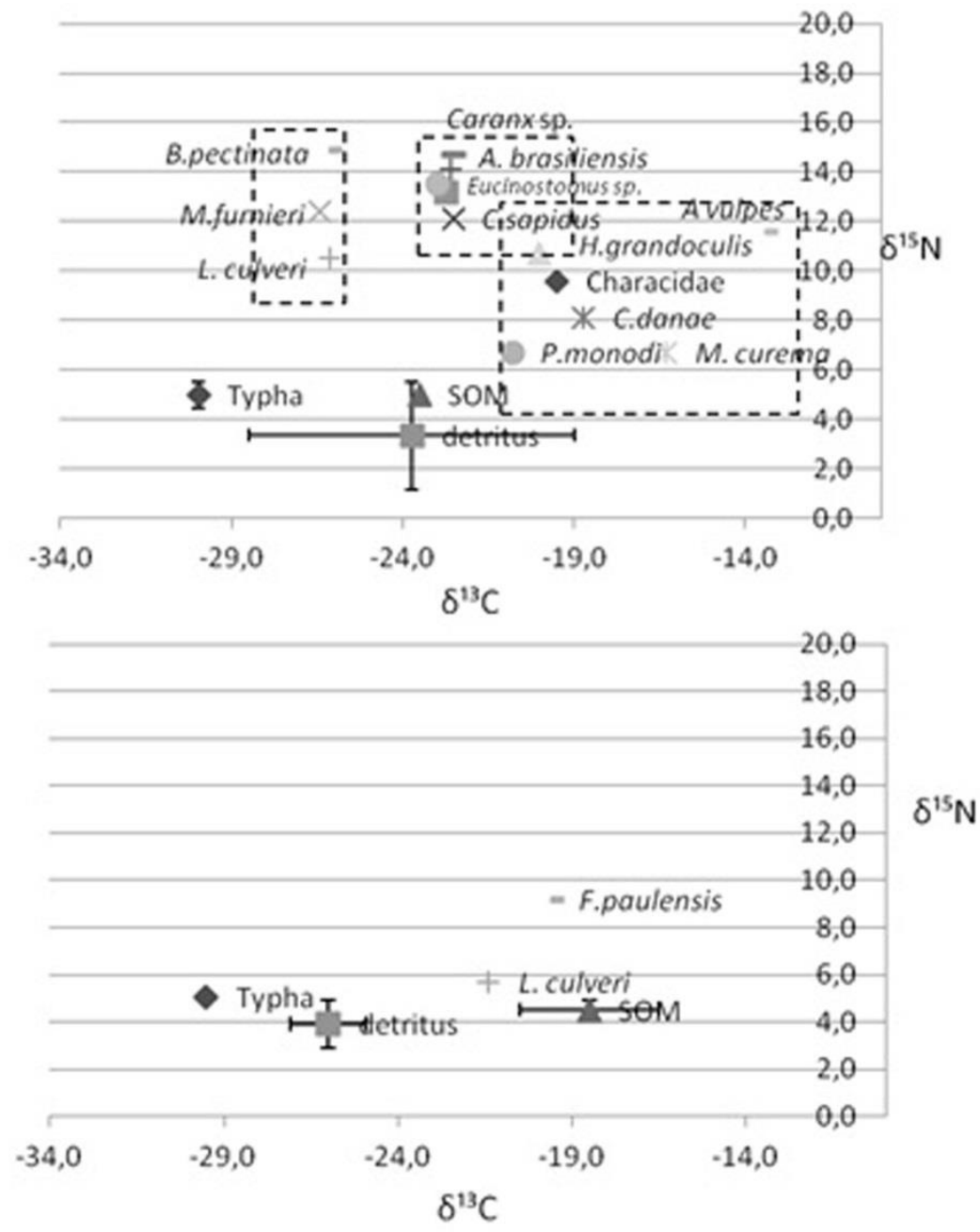

Fig. 4. Scatter plots showing stable isotope signatures for consumers. 
Micropogonias furnieri is a carnivorous benthic feeder (ISAAC, 1988), and its isotopic composition may suggest that it feeds on polychaetes or other animals that have not been included in the samples collected. A second group is represented by consumers depending mostly on detritus and SOM, and includes the crustacean Callinectes sapidus and fishes Atherinella brasiliensis, Caranx sp. and Eucinostomus sp. A third group comprises consumers depending on ${ }^{13} \mathrm{C}$-enriched sources not sampled in the present study, although a certain role of SOM and detritus could not be ruled out. It includes the crustacean Platorchestia monodi and the fish Mugil curema both of which are primary consumers, followed by the crustacean $C$. danae, which may be an omnivorous consumer and by fishes belonging to Characidae, $H$. grandoculis and Albula vulpes classified as carnivores, the last of higher trophic level. In Guarapina, polychaete $L$. culveri's signature suggests that it may feed on detritus and SOM, whereas $F$. paulensis depends exclusively on SOM.

Stable isotopes of consumers suggest the major dependence of their diet in both compartments on sedimentary organic matter and detritus. The overlapping isotopic composition of SOM and detritus does not allow the identification of the trophic contribution of each source. However, SOM and detritus are usually the most representative and important sources, especially in systems such as coastal lagoons where low hydrodynamics contribute to the accumulation and sinking of vascular matter, which is transformed by bacteria into a more favourable form (VIZZINI; MAZZOLA, 2006). We cannot rule out a contribution of phytoplankton to sedimentary organic matter through sedimentation processes, as it is a common aspect in semi-enclosed systems with low turnover rates (PUSCEDDU et al., 1997). Microscope observation coupled with the high $\mathrm{C} / \mathrm{N}$ and stable isotope ratios suggest a clear contribution of macrophytes to the detritus pool. As seagrasses are not present within the lagoonal system, the main detrital source seems to be Typha. As a consequence macrophytes could play an indirect role through the detritus pathway, although not great because of the high $\mathrm{C} / \mathrm{N}$ which suggests availability of non-labile organic matter. According to the literature (RODRIGUEZ-GRANA et al., 2008), direct consumption seems to be of minor importance. It is well known that macrophytes have a low nutritional content and, further, that because they are rich in structural carbohydrates they are not easy for consumers to digest (BOUILLON et al. 2000; BOUILLON et al., 2002); however, their detritus undergoes improvement in its nutritional status due to microbial colonization (VIZZINI 2009).
As a general result, when comparing the stable isotope composition of consumers from the two compartments sampled, and although the number of species sampled in Guarapina is very limited, there is evidence of an overall enrichment in the carbon heavy isotope in the Guarapina compartment. Results suggest that the Maricá and Guarapina compartments differ in terms of freshwater and external anthropogenic inputs: the former receives freshwater inputs and probably river-borne nutrients and organic matter, while the second is more likely to be mainly affected by opensea vivification. A lesser freshwater input into the Guarapina compartment could be the main reason for the more enriched $\delta^{13} \mathrm{C}$ values in that area's SOM. Rivers, in fact, contribute with very $\delta^{13} \mathrm{C}$ depleted organic matter (VIZZINI et al., 2005b), as was encountered in Maricá. Terrigenous organic matter may have a greater influence on the Maricá compartment rather than on Guarapina, as there is freshwater input in the former area. In fact more than one river (Rio Camburì, Rio Monruca, brook do Buriche) flows into the Maricá compartment and a long channel connects it to a small waterbody called Lagoa Brava (see fig. 1), which might also contribute with freshwater inputs. On the other hand, only one river with a low rate of flow (Rio Caranguejo) flows into the Guarapina compartment.

\section{Conclusion}

In conclusion, differences between abiotic features in the lagoon system of Maricá-Guarapina have influenced the different species' distribution but not the biodiversity levels, which appear to be homogeneous in both compartments and are characterised by low-diversity. This study has shown that macrozoobenthic species tend to change with increasing distance from the sea, with a slightly different distribution in the two compartments. Vegetation represented by $T$. domingensis does not have an influence on biotic distribution and, furthermore, it has not been demonstrated that $T$. domingensis may be the main food supply for consumers in the lagoon system where, instead, sedimentary organic matter and macrophyte detritus seem to play a major role in the trophic web. Nevertheless, further analyses in different seasons (dry versus wet) are required, in order to better understand the role of macrophites and of sedimentary organic matter to determine trophic webs with the use of stable isotope analyses and to make a more complete comparison between the two compartments of the lagoon, with a view to detecting possible anthropogenic, continental and marine influences (e.g. phytoplankton, tidal range) on the ecosystem. 


\section{ACKNOWLEDGMENTS}

We thank the staff of the Laboratorio de Ecologia de Sedimentos of the Departemento de Biologia Marinha, Universidade Federal Fluminense in Rio de Janeiro, where the sampling, classification and processing was carried out. We are especially grateful to C.L. Mendes, for her fundamental help, which greatly improved this work and to P. Mazurek, T. Costa, G. Neves de Souza for their laboratory and field assistance. We also thank E. Aleo (Università di Palermo), for help in the SIA. This research was carried out for a master's degree thesis at the Universidade Fluminense de Rio de Janeiro, Brazil and Università di Pisa, Italy.

\section{REFERENCES}

ANDERSON, M. J. A new method for non-parametric multivariate analysis of variance. Austral Ecol., v. 26, p. 32-46, 2001.

BARROSO-VANACÔR, L.; PERRIN, P.; CARMOUZE, J. $P$. Le système lagunaire de Maricá-Guarapina (Brésil) et ses modifications écologiques récentes d'origine antropique. Rev. Hydrobiol. Trop., v. 27, n. 3, p. 189197, 1994.

BOUILLON, S.; CHANDRA MOHAN, P. C.; SREENIVAS, N.; DEHAIRS, F. Sources of suspended organic matter and selective feeding by zooplankton in an estuarine mangrove ecosystem as traced by stable isotopes. Mar. Ecol. Prog. Ser., v. 208, p. 79-92, 2000.

BOUILLON, S.; RAMAN, A. V.; DAUBY, P.; DEHAIRS, F. Carbon and nitrogen stable isotope ratios of subtidal benthic invertebrates in an estuarine mangrove ecosystem (Andhra Pradesh, India). Estuar. Coast. Shelf Sci., v. 54, p. 901-913, 2002.

BYERS, S.; MILIS C.; STEWARD. P. L. A comparison of methods of determining organic carbon in marine sediments with suggestions for a standard method. Hydrobiologia, v. 58(1), p. 43-47. 1978.

CAMARGO, M. G. SYSGRAN para Windows: Sistema de análises granulométricas. 2006.

CADÉE, G. C.; HEGEMAN, J. Primary production of the benthic microflora living on tidal flats in the Dutch Wadden Sea, Netherlands. J. Sea Res., v. 8, n. 2/3, p. 260-291, 1974.

CARABEL, S.; GODINEZ-DOMINGUEZ, E.; VERISIMO, P.; FERNANDEZ, L., FREIRE, J. An assessment of sample processing methods for stable isotope analyses of marine food webs. J. Exp. Mar. Biol. Ecol., v. 336, n. 2, p. 254-261, 2006.

CARMOUZE, J. P.; KNOPPERS, B.; VASCONCELOS, P. Metabolism of a subtropical Brazilian lagoon. Biogeochemistry, v. 14, p. 129-148, 1991.

CLARKE, K. R. Non-parametric multivariate analyses of changes in community structure. Aust. J. Ecol., v. 18, p. 117-143, 1993.

CLARKE, K. R. \& WARWICK, R. M. Change in marine communities: an approach to statistical analysis and interpretation. 2.ed. Plymouth: PREMIER-E, 2001. 172 p.
COMO, S.; MAGNI, P.; CASU, D.; FLORIS, A.; GIORDANI, G.; NATALE, S.; FENZI, G. A.; SIGNA, G.; DE FALCO, G. Sediment characteristics and macrofauna distribution along a human-modified inlet in the Gulf of Oristano (Sardinia, Italy). Mar. Pollut. Bull., v. 54, p. 733-744, 2007.

CROSSLAND, C. J.; KREMER H. H.; LINDEBOOM, H. J.; MARSHALL CROSSLAND, J. I.; LE TISSIER, M. D. A. (Eds). Coastal fluxes in the Anthropocene. Berlin: Springer, 2005. 231 p. (Global Change - The IGBP series). [The Land-Ocean Interactions in the Coastal Zone Project of the International Geosphere-Biosphere Programme].

DE FALCO, G., MAGNI, P., TERASVUORI, L. M. H., MATTEUCCI, G. Sediment grain-size and organic carbon distribution in the Cabras lagoon (Sardinia, west Mediterranean). Chemistry and Ecology 20 (Supplement 1), S367-S377, 2004.

DRAKE, P.; ARIAS, A.M. The effect of aquaculture practices on the benthic macroinvertebrate community of a lagoon system in the Bay of Cadiz (southwestern Spain). Estuaries, v. 20, p. 677-688, 1997.

ESTEVES, F. Lagoas costeiras: origem, funcionamento e possibilidade de manejo. In: ESTEVES, F. A. (Ed.). Ecologia das lagoas costeiras do Parque Nacional da Restinga de Jurubatiba e do Município de Macaé (RJ). Rio de Janeiro: Núcleo de Pesquisa Ecológicas de Macaé (NUPEM) - UFRJ, 1998. cap. 2.2, p. 63-87.

FIGUEIREDO-BARROS, M. P., LEAL, J. J. F., ESTEVES, F. A., ROCHA, A. M., BOZELLI, R. L. Life cycle, secondary production and nutrient stock in Heleobia australis (d'Orbigny 1835) (Gastropoda: Hydrobiidae) in a tropical coastal lagoon. Estuar., Coast. Shelf Sci. (Print), v. 69, p. 87-95, 2006.

FOLK, R. L.; WARD, W. C. Brazos River bar: a study of the significance of grain size parameters. J. Sediment. Petrol., v. 27, p. 3-26, 1957.

FRY, B, SHERR, E. $\delta^{13} \mathrm{C}$ measurements as indicators of carbon flow in marine and freshwater ecosystems. Contrib. Mar. Sci., v. 27, p. 13-47, 1984.

GAMBI, C.; TOTTI, C.; MANNINI, E. Impact of organic loads and environmental gradients on microphytobenthos and meiofaunal distribution in a coastal lagoon. Chem. Ecol., v. 19, p. 207-223, 2003.

GIANGRANDE, A.; FRASCHETTI, S. Effects of a shortterm environmental change on a brackish-water polychaete community. Mar. Ecol., v. 17, n. 1/3, p. 321332, 1996.

GOMES, A. S. \& PALMA, J. J. C. Causas e consequências do impacto ambiental da exploração dos recursos minerais marinhos. Brazilian Journal of Geophysics. v. 18(3), p. 447-454. 2000.

GOMES, A. S.; PAIVA, P. C.; PITOMBO, F. B. Bentos de sedimentos inconsolidados. In: PEREIRA, R. C.; SOARES-GOMES, A. (Eds.). Biologia Marinha. 2.ed. Rio de Janeiro: Interciência, v. 1, p. 319-337. 2009.

GUERRA, L. V.; SAVERGNINI, F.; SILVA, F. S.; BERNARDES, M. C.; CRAPEZ, M. A. C. Biochemical and microbiological tools for the evaluation of environmental quality of a coastal lagoon system in southern Brazil. Braz. J. Biol., v. 71, n. 2, p. 461-468, 2011. 
HENRIQUES-DE-OLIVEIRA， C.; BAPTISTA， D. F.; NESSIMIAN, J. L. Sewage input effects on the macroinvertebrate community associated to Typha domingensis Pers in a coastal lagoon in southeastern Brazil. Braz. J. Biol., v. 67, n.1, p. 73-80, 2007.

ISAAC, V. J. Synopsis of biological data on the whitemouth croaker: Micropogonias furnieri (Desmarest, 1823). Rome: Food and Agriculture Organization of the United Nations, 1988. (FAO Fisheries Symposis, n. 150).

JARDINE, T. D.; McGEACHY, S. A.; PATON, C. M.; SAVOIE, M.; CUNJAK, R. A. Stable isotopes in aquatic systems: sample preparation, analysis, and interpretation. Fredericton: Stable Isotopes in Nature Laboratory, Canadian Rivers Institute, University of New Brunswick, 2003. 39 p. (Canadian Manuscript Report of Fisheries and Aquatic Sciences, v. 2656).

JORGENSEN, P.; BEMVENUTI, C. E.; HEREU, C. M. Feeding of Farfantepenaeus paulensis (Pérez-Farfante, 1967) (Crustacea: Penaeidae) inside and outside experimental pen-culture in southern Brazil. Pan-Am. J. Aquat. Sci., v. 4, n. 1, p. 39-51, 2009.

KJERFVE, B. (Ed.). Coastal lagoon processes. Amsterdam: Elsevier, 1994. p. 311-362. (Elsevier Oceanographic Series; 60).

KJERFVE, B. Comparative oceanography of coastal lagoons. In: WOLFE, D. A. (Ed.). Estuarine variability. San Diego: Academic Press, 1986. p. 63-81. [International Estuarine Research Conference, 8, New Hampshire, Durham, 1985].

KNOPPERS, B. Aquatic primary production in coastal lagoons. In: Kjerfve B. (Ed.). Coastal lagoon processes. Elsevier, Amsterdam, 1994. p. 243-286.

KNOPPERS, B.; CARMOUZE, J. P.; MOREIRA-TURCQ, P. F. Nutrient dynamics, metabolism and eutrophication of lagoons along the East fluminense coast, State of Rio de Janeiro, Brazil. In: KNOPPERS, B. A.; BIDONE, E. D.; ABRAO, J. J. (Eds). Environmental geochemistry of coastal lagoon systems of Rio de Janeiro, Brazil: geoquímica ambienta de sistemas lagrinaves do Rio de Janeiro, Brasil. Niterói: UFF/Programa de Geoquímica Ambiental, 1999. p. 123-154. (Serie Geoquímica Ambiental, 6).

KNOPPERS, B.; KJERFVE, B.; CARMOUZE, J. P. Trophic state and water turn-over time in six choked coastal lagoons in Brazil biogeochemistry. Biogeochemistry, v. 14, n. 2, p. 149-166, 1991.

LARDICCI, C.; ABBIATI, M.; CREMA, R.; MORRI, C.; BIANCHI, C. N.; CASTELlI, A. The distribution of Polychaetes along environmetal gradientes: an exemple from the Orbetello Lagoon (Italy). Mar. Ecol., v. 14, n. 1, p. 35-52, 1993.

LARDICCI, C.; COMO, S.; CORTI, S.; ROSSI, F. Changes and recovery of macrozoobenthic communities after restoration measures of the Orbetello Lagoon (Tyrrhenian coast, Italy). Aquat. Conserv. Mar. Freshwater Ecosyst., v. 11, n. 4, p. 281-287, 2001.

LARDICCI, C.; ROSSI, F.; CASTELLI, A. Analysis of macrozoobenthic community structure after severe dystrophic crises in a mediterranean coastal lagoon. Mar. Pollut. Bull., v. 34, p. 536-547, 1997.

LINDEGARTH, M., HOSKIN, M. Patterns of distribution of macro-fauna in different types of estuarine, soft sediment habitats adjacent to urban and non-urban areas. Estuar., Coast. Shelf Sci., v. 52, p. 237-247. 2001.

LORENZEN, C. Determination of chlorophyll and pheopigments: spectrophotometric equations. Limnol. Oceanogr., v. 12, p. 343-346, 1967.

MADUREIRA CRUZ, C. B; CARVALHO Jr., W.; BARROS, R. S.; ARGENTO, M. S. F.; MAYR, L. M. Impactos ambientais no sistema lagunar de MaricáGuarapina. In: SIMPÓSIO BRASILEIRO DE SENSORIAMENTO REMOTO, 8., Salvador, 1996. Anais. Salvador: INPE, 1996. p. 137-141.

MAGNI, P.; RAJAGOPAL, S.; VAN DER VELDE, G.; FENZI, G.; KASSENBERG, J.; VIZZINI, S.; MAZZOLA, A.; GIORDANI, G. Sediment features, macrozoobenthic assemblages and trophic relationships $\left(\delta^{13} \mathrm{C}\right.$ and $\delta^{15} \mathrm{~N}$ analysis) following a dystrophic event with anoxia and sulphide development in the Santa Giusta lagoon (western Sardinia, Italy). Mar. Pollut. Bull., v. 57, p. 125-136, 2008.

MARZANO, C. N.; GRAVINA, M. F.; FIANCHINI, A.; PORTACCI, G.; GHERARDI, M.; TURSI, A.; CORRIERO, G. The macrozoobenthos of the Karavasta lagoon system (Albania): local assemblages and geographical comparisons. Mar. Ecol., v. 31, p. 622$632,2010$.

MAZURKIEWICZ, M. Larval development and habits of Laeonereis culveri (Webster) (Polychaeta: Nereidae). Biol. Bull., v. 149, n. 1, p. 186-204, 1975.

MENDES, C.L.T.; TAVARES, M.; SOARES-GOMES, A. Taxonomic sufficiency for soft-bottom sublittoral mollusks assemblages in a tropical estuary, Guanabara Bay, southeast Brazil. Mar. Pollut. Bull., v. 54, n. 4, p. 377-384, 2007

MIKAC K.M., MAHER W., JONES A. Physico-chemical sediment variables and soft sediment macrofauna in microsize coastal lagoons and their catchments in New South Wales, Australia. Estuar., Coast. Shelf Sci., v. 72, p. 308-318. 2007.

MILLET B. and GUELORGET O. Spatial and seasonal variability in the relationships between benthic communities and physical environment in a lagoon ecosystem. Marine Ecology Progress Series, v. 198, p. 161-174.1994

MORENO, I. M.; ÁVILA, A.; LOSADA, M. A. Morphodynamics of intermittent coastal lagoons in southern Spain: Zahara de los Atunes. Geomorphology, 121, n. 3/4, p. 305-316, 2010.

MORINO, H.; ORTAL, R. Two Platorchestia Species (Amphipoda, Talitridae) from Israel. Crustaceana, v. 68, n. 7, p. 824-832, 1995.

MOUILLOT, D.; GAILLARD, S.; ALIAUME, C.; VERLAQUE, M.; BELSHER, T.; TROUSSELLIER, M.; CHI, T. D. Ability of taxonomic diversity indices to discriminate coastal lagoon environments based on macrophyte communities. Ecol. Indic., v. 5, n. 1, p. 117, 2005.

NAKAMURA, I.; INADA, T.; TAKEDA, M.; HATANAKA, H. Important fishes trawled off Patagonia. Tokyo: Japan Marine Fishery Resource Research Center, 1986. p. 72.

NEVES, R. A. F.; VALENTIN, J. L.; FIGUEIREDO, G. M. Morphological description of the gastropod Heleobia australis (Hydrobiidae) from egg to hatching. Braz. J. Oceanogr., v. 58, n. 3, p. 247-250, 2010. 
NIXON, S. W.; BUCKLEY, B. A.; GRANGER, S. L.; ENTSUA-MENSAH, M.; ANSA-ASARE, O.; WHITE, M. J.; MCKINNEY, R. A.; MENSAH, E. Anthropogenic enrichment and nutrients in some tropical lagoons of Ghana, west Africa. Ecol. Appl., v. 17, p. S144-S164, 2007.

PAMPLIN, P. A. Z.; ALMEIDA, T.; SILVA-FILHO, J. P. New record of Laeonereis acuta (Treadwell, 1923) (Nereididae: Polychaeta) in northeast coast of Brazil. Biota Neotropica, v. 7, n. 3, p. 353-355, 2007.

PERTHUISOT, J. P.; GUELORGET, O. Le domaine paralique: expressions géologiques, biologiques et économiques du confinement. Paris: Presses de l'École Normale Supérieure de Paris, 1983. 136 p. (Travaux du Laboratoire de Géologie, École Normale Supérieure, 16).

PETERSON, B.; FRY, B. Stable isotopes in ecosystem studies. Annu. Revue Ecol. Syst., v. 18, p. 293-320, 1987.

PLANTE-CUNY, M.R. - Spectrophotometric Evaluation of non Degradated Chlorophyll a and Pheopigments content of the Marine Sediments. Trav. Doc. ORSTOM. NosyBe (Madagascar). v. 45, p. 63-76. 1974.

PLANTE-CUNY, M. R. Pigments photosynthétiques et production primaire des fonds meubles néritiques d'une région tropicale (Nosy-Bé, Madagascar). Trav. Doc. ORSTOM, v. 96, p. 1-359, 1978.

PONTI, M.; COLANGELO, M. A.; CECCHERELLI, V. U. Composition, biomass and secondary production of the macrobenthic invertebrate assemblages in a coastal lagoon exploited for extensive aquaculture: Valle Smarlacca (northern Adriatic Sea). Estuarine, Coastal Shelf Sci., v. 75, p. 78-79, 2007.

POST, D.M.. Using stable isotopes to estimate trophic position: models, methods, and assumptions. Ecology, v83(3), p. 703-718. 2002.

PUSCEDDU, A.; SARÀ, G.; MAZZOLA, A.; FABIANO, M. Relationship between suspended and sediment organic matter in a semi-enclosed marine system: the Stagnone di Marsala sound (Western Sicily). Water, Air, Soil Pollut., v. 99, p. 343-352, 1997.

RODRIGUEZ-GRANA, L.; CALLIARI, D.; CONDE, D.; SELLANES, J.; URRUTIA, R. Food web of a SW Atlantic shallow coastal lagoon: spatial environmental variability does not impose substantial changes in the trophic structure. Mar. Ecol.: Prog. Ser., v. 362, p. 6983, 2008.

ROSSI, F.; CASTELLI, A.; LARDICCI, C. Distribution of macrobenthic assemblages along a marine gradient in Mediterranean eutrophic coastal lagoons. Mar. Ecol., v. 27 , p. 66-75, 2006.
SILVA, E. P.; FERNANDES, F. C.; SOARES-GOMES, A.; ABREU, C. M. R. C. Sandy beach macrobenthos assemblages at an hypersaline coastal lagoon, Lagoa de Araruama, RJ. Braz. J. Coastal Res., v. 42, sp.n., p. 265-270, 2005

SNELGROVE, P. V.; BUTMAN, C. A. Animal-sediment relationships revisited: cause versus effect. Oceanogr. Mar. Biol., v. 32, p. 111-177, 1994

SOFFIATI, A. Aspectos históricos das lagoas do Norte do Estado do Rio de Janeiro. In: ESTEVES, F. A. (Ed.). Ecologia das lagoas costeiras do Parque Nacional da Restinga de Jurubatiba e do Município de Macaé (RJ). Rio de Janeiro: Núcleo de Pesquisa Ecológicas de Macaé (NUPEM) - UFRJ, 1998. cap. 1, p. 3-35.

VIZZINI, S.; MAZZOLA, A. Seasonal variations in the stable carbon and nitrogen isotope ratios $\left({ }^{13} \mathrm{C} /{ }^{12} \mathrm{C}\right.$ and ${ }^{15} \mathrm{~N} /{ }^{14} \mathrm{~N}$ ) of primary producers and consumers in a western Mediterranean coastal lagoon. Mar. Biol., v. 142, p. 1009-1018, 2003.

VIZZINI, S.; SAVONA, B.; DO CHI, T.; MAZZOLA, A. Spatial variability of stable carbon and nitrogen isotope ratios in a Mediterranean coastal lagoon. Hydrobiologia, v. 550 , p. $73-82,2005$ a.

VIZZINI, S.; SAVONA, B.; CARUSO, M.; SAVONA, A.; MAZZOLA, A. Analysis of stable carbon and nitrogen isotopes as a tool for assessing the environmental impact of aquaculture: a case study from the western Mediterranean. Aquacult. Int., v. 13, p. 157-165, 2005 b.

VIZZINI, S.; MAZZOLA, A. Sources and transfer of organic matter in food webs of a Mediterranean coastal environment: evidence of spatial variability. Estuarine, Coastal Shelf Sci., v. 66, p. 459-467, 2006.

VIZZINI, S.; MAZZOLA, A. The fate of organic matter sources in coastal environments: a comparison of three Mediterranean lagoons. Hydrobiologia, v. 611, p. 6779, 2008.

VIZZINI S. Analysis of the trophic role of Mediterranean seagrasses in marine coastal ecosystems: a review. Botanica Marina, v. 52, p. 383-393. 2009

(Manuscript received 21 October 2012; revised 03 June 2013; accepted 24 June 2013) 